\title{
In Vitro Assessment of Gentamicin Cytotoxicity on the Selected Mammalian Cell Line (Vero cells)
}

\author{
Anton Kovacik $^{1^{\star}}$, Eva Tvrda1, Diana Fulopova ${ }^{2}$, Peter Cupka ${ }^{1}$, Eva Kovacikova ${ }^{3}$, \\ Katarina Zbynovska ${ }^{1}$, Peter Massanyi ${ }^{1}$ \\ ${ }^{1}$ Department of Animal Physiology, Faculty of Biotechnology and Food Sciences, Slovak University of \\ Agriculture in Nitra, 949 76-Nitra, Tr. A. Hlinku 2, Slovak Republic \\ ${ }^{2}$ Institute for State Control of Veterinary Biologicals and Medicines, 949 01-Nitra, Biovetska 34, Slovak \\ Republic \\ ${ }^{3}$ Research Centre AgroBioTech, Slovak University of Agriculture in Nitra, 949 76-Nitra, Tr. A. Hlinku 2, \\ Slovak Republic
}

\begin{abstract}
The aim of this study was to evaluate the in vitro cytotoxicity of different concentrations $(500-7500 \mu \mathrm{g} / \mathrm{mL})$ of gentamicin - GENT (aminoglycoside antibiotic) on the selected mammalian cell line (Vero - cell line from African green monkey kidney). Analysis of the cell morphological changes was microscopically evaluated (magnification x 400). Quantification of $\mathrm{Ca}, \mathrm{Mg}$ and total proteins was performed using spectrophotometry on device Rx Monza (Randox). Quantification of $\mathrm{Na}, \mathrm{K}$ and $\mathrm{Cl}$ was performed on the automatic analyzer EasyLyte. The cell viability was assessed using the metabolic mitochondrial MTT test. Vero cells were able to survive at concentrations of $500(89.21 \%), 1000$ $(79.54 \%)$ and $2000 \mu \mathrm{g} / \mathrm{mL}(34.59 \%)$. We observed statistically significant decrease of vital cell content at concentrations of $2000,4500,7500 \mu \mathrm{g} / \mathrm{mL}$ against control group. Vero cell line slightly reacted to the presence of GENT but total proteins and mineral parameters were not significantly affected. Vero cells were highly sensitive to GENT with a significant decrease of viability at concentrations of 2000 and $4500 \mu \mathrm{g} / \mathrm{mL}(P<0.001)$. Our data reveal that GENT has a significant cytotoxic and adverse effect on the cell viability.
\end{abstract}

Keywords: cytotoxicity, gentamicin, mitochondrial activity, Vero cell line.

\section{Introduction}

Aminoglycoside antibiotics were discovered in the middle of last century. Their antimicrobial effects stimulated their large usage in medicine. Aminoglycoside antibiotics (the most commonly used antibiotics worldwide) are effective against gram-negative bacterial infections [1, 2].

Gentamicin (GENT) belongs to the aminoglycoside class of bactericidal antibiotic. Gentamicin is a mixture of $\mathrm{C}_{1}, \mathrm{C}_{1 \mathrm{a}}$, and the enantiomers $\mathrm{C}_{2}$ and $\mathrm{C}_{2 a}$ elaborated by

\section{* Corresponding author: Anton Kovacik, anton.kovacik@yahoo.com}

(cc) BY-NC-ND $\odot 2017$ Anton Kovacik et al., published by De Gruyter Open. This work was licensed under the Creative Commons Attribution-NonCommercialNoDerivs 3.0 License
Micromonospora spp. with glycosidic linkages at positions 4 and 6 [3] and is active against a broad range of bacterial infections, especially Gramnegative bacteria including Pseudomonas, Proteus, Escherichia coli, Klebsiella pneumoniae, Enterobacter aerogenes, Serratia, and Staphylococcus $[1,4,5]$.

The frequent use of gentamicin, not only in medicine, but also in agriculture and veterinary medicine had proved ototoxic [6] and nephrotoxic side effect [7]. Gentamicin-induced nephrotoxicity mainly includes renal inflammatory cascades, high renal oxidative stress, associated pathological signaling mechanisms and renal dysfunction [2]. Also, are known the possible cytotoxic $[8,9,10]$ and hepatotoxic [11] effects of gentamicin. 
These effects might be due to differences of gentamicin concentrations. However, there is still a lack of data about the aminoglycosides effect on cell morphology in in vitro studies [12].

For this reason, the goal of our study was to evaluate the in vitro cytotoxicity of different concentrations of gentamicin on the selected mammalian cell culture (Vero - cell line from African green monkey kidney).

\section{Material and Methods}

In our experiments, we used Vero cell line (cell line from African green monkey kidney). Cell line was obtained from cellular collections of the Department of Bio Preparations, Institute for State Control of Veterinary Biopreparations and Medicines in Nitra (Slovak Republic). Cells were revived according to appropriate protocols (ŠPP ÚŠKVBL Nitra 007) optimized for our laboratories. Cells were transferred into the sterile Roux flasks (DMEM/F12 supplemented with $20 \%$ FCS, nonessential amino acids, glutamine, LIF, fibroblast growth factor-2, beta-mercaptoethanol and antibiotics for Vero cells) following revival and cultivated at $37^{\circ} \mathrm{C}$. After 24 hours was determined cell density in the monoculture. Cell suspension was prepared cell dilution using Fetal Bovine Serum enriched culture medium. Obtained cell suspensions were transferred into 48 well plates with $500 \mu \mathrm{l}$ per well. After incubation in Fetal Bovine Serum enriched culture media, the cells were microscopically observed. When a singlelayer was coherent, the medium was removed and prepared gentamicin was applied on cells $[13$, 14].

For testing of Vero cells, we chose gentamicinGENT (Intervet, MSD Animal Health, South Africa). The concentrations, used in our study, were obtained on the basis of knowledge for the minimum inhibitory concentrations of GENT effect on bacteria and LD50 for laboratory animals. These contents of gentamicin are nontoxic for eukaryotic cells, for that we raised them 1000times. Then they were modified to concentration, which is toxic (LD100). These concentrations were used as zero dilution, titration continued with a decimal dilution. Chosen concentrations of GENT used in our experiment are showed in Table 1. The final cell culture was cultured for $24 \mathrm{~h}$ $[13,14]$. Concentrations of GENT for all analyses were selected for monitoring its increasing effect. After application of different concentrations of GENT, we microscopically controlled the condition of cells in the plates (magnification $x 400$ ). We observed the structural changes of cells and we assess the quantity of vital, subvital and dead cells $[13,15]$.
Table 1

Concentrations of gentamicin used for the analyses

\begin{tabular}{c|c|c}
\hline Cell vitality & $\begin{array}{c}\text { Minerals and } \\
\text { TP }\end{array}$ & Viability \\
\hline \multicolumn{2}{c}{ Concentrations of GENT $(\mu \mathrm{g} / \mathrm{mL})$} \\
\hline $0^{*}$ & $0^{*}$ & $0^{*}$ \\
1000 & 650 & 1000 \\
2000 & 1500 & 2000 \\
4500 & 4500 & 4500 \\
7500 & & \\
\hline
\end{tabular}

${ }^{*}$ Control

After 24 hours exposure of selected cells to GENT, cultivating medium was collected for future analyses in micro tubes to $-20^{\circ} \mathrm{C}$. Frozen medium was used for total proteins and mineral profile analyses for the purpose of determination of possible antibiotic effect on cell metabolism. Quantification of Calcium (Ca), Magnesium (Mg) and total proteins (TP) was performed using spectrophotometry. Analyses were realized in the biochemical and hematological laboratory from the Department of Animal Physiology of Slovak University of Agriculture in Nitra using commercial sets DiaSys (Diagnostic Systems $\mathrm{GmbH}$, Germany) on semi-automatic analyzer Rx Monza (Randox Laboratories Ltd., United Kingdom). Quantification of Sodium ( $\mathrm{Na}$ ), Potassium $(\mathrm{K})$ and Chloride $(\mathrm{Cl})$ was performed by the automatic analyzer EasyLyte (Medica, Bedford, USA) [16].

Viability of the cells exposed to GENT in vitro was tested using the metabolic activity (MTT) assay [17]. This colorimetric assay measures the conversion of 3- (4,5-dimetylthiazol-2-yl)-2,5diphenyltetrazolium bromide (MTT; Sigma-Aldrich, St. Louis, USA) to purple formazan particles by mitochondrial succinate dehydrogenase of intact mitochondria of living cells. The resulting formazan was measured spectrophotometrically at wavelength of $570 \mathrm{~nm}$ against $620 \mathrm{~nm}$ as reference by a microplate ELISA reader (Multiskan FC, Thermo Fisher Scientific, Finland). The data are expressed in percentage of control (i.e. optical density of formazan from cells not exposed to the antibiotic) [14]. MTT viability test was repeated three times for each antibiotic concentration.

To test for differences between the control and experimental groups was used one-way analysis of variance (ANOVA), with the Scheffe's test. The level of significance was set at ${ }^{* * *}(P<0.001)$; ${ }^{* *}(P<0.01) ;{ }^{*}(P<0.05)$.

\section{Results and Discussions}

A dose-dependent toxic effect of GENT on cell viability was observed after administration to Vero 
cell cultures. The selected cell line exhibited the statistical significant $(p<0.001)$ degree of susceptibility to the antibiotic at 2000,4500 and $7500 \mu \mathrm{g} / \mathrm{mL}$ concentrations. On the other hand, Vero cells were resistant to the GENT at 1000 $\mu \mathrm{g} / \mathrm{mL}$ concentration (Figure 1). Microscopic observation of the cell viability of Vero cell cultures is shown in Figure 2.

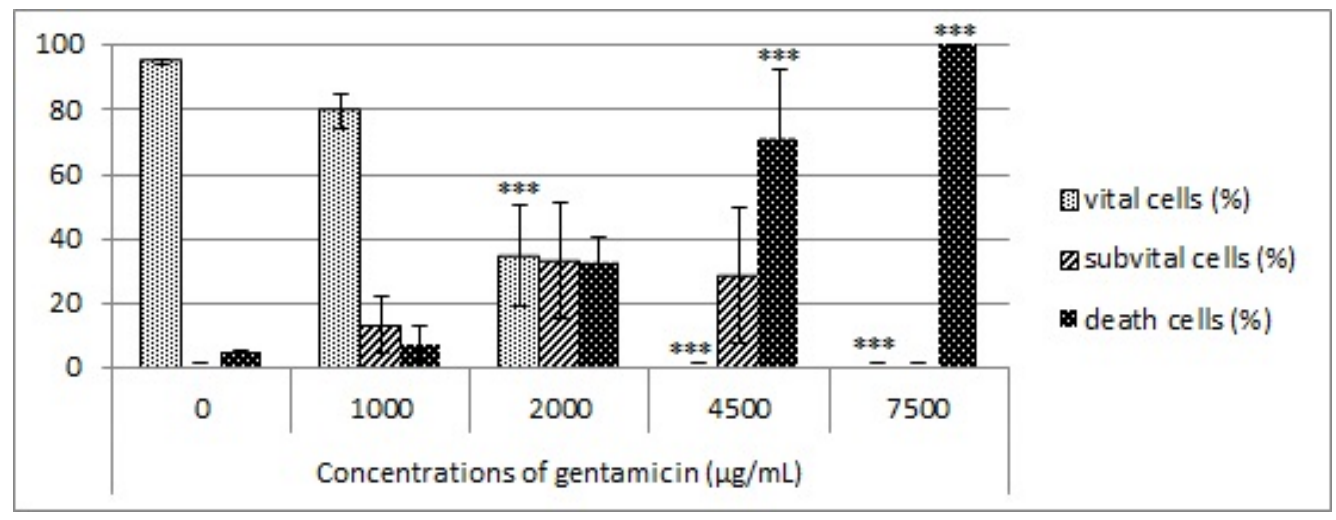

Figure 1. Cell viability (\%) evaluation of Vero cell after GENT administration versus control, ${ }^{* * *}(\mathrm{P}<0.001)$; ${ }^{* *}(\mathrm{P}<0.01) ;{ }^{*}(\mathrm{P}<0.05)$.
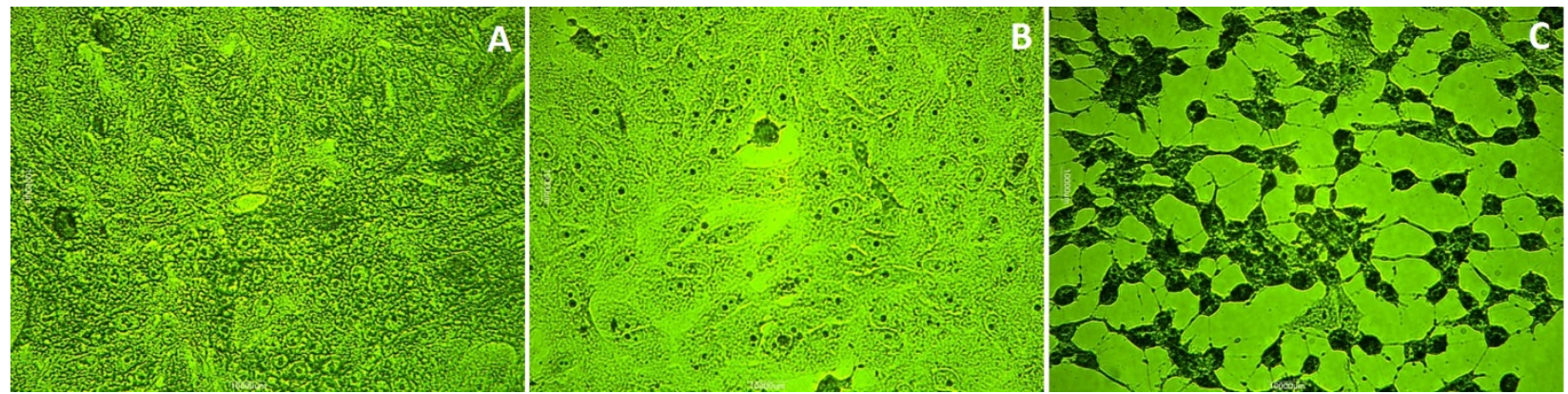

Figure 2. Phase contrast images of Vero cells; A) $0 \mu \mathrm{g} / \mathrm{mL}$ of GENT (control); B) Vero cells after exposure to GENT (1000 $\mu \mathrm{g} / \mathrm{mL})$; and C) Vero cells after exposure to GENT (4500 $\mu \mathrm{g} / \mathrm{mL})$ for 24 hours (magnification $\times$ 400)

Although Vero cell lines reacted to the presence of GENT, total proteins content and mineral parameters in the medium were not significantly affected (Figure 3). Yu et al. [18] tested gentamicin on vestibular hair cells (VHCs II) and their findings indicated that increasing of $\mathrm{Ca}^{2+}$ could antagonize GENT blocking effect; also, GENT may block the dependent $\mathrm{K}^{+}$channels by impairing calcium influx.
Dose-responses of the gentamicin measured by the MTT test are shown in Figure 4. Gentamicin supplementation revealed to have toxic effects on the Vero cell line. Vero cells exhibited high sensitivity to the antibiotic, as GENT concentrations were higher than $2000 \mu \mathrm{g} / \mathrm{mL}$ and led to a significant decrease $(P<0.001)$ of the mitochondrial activity. 


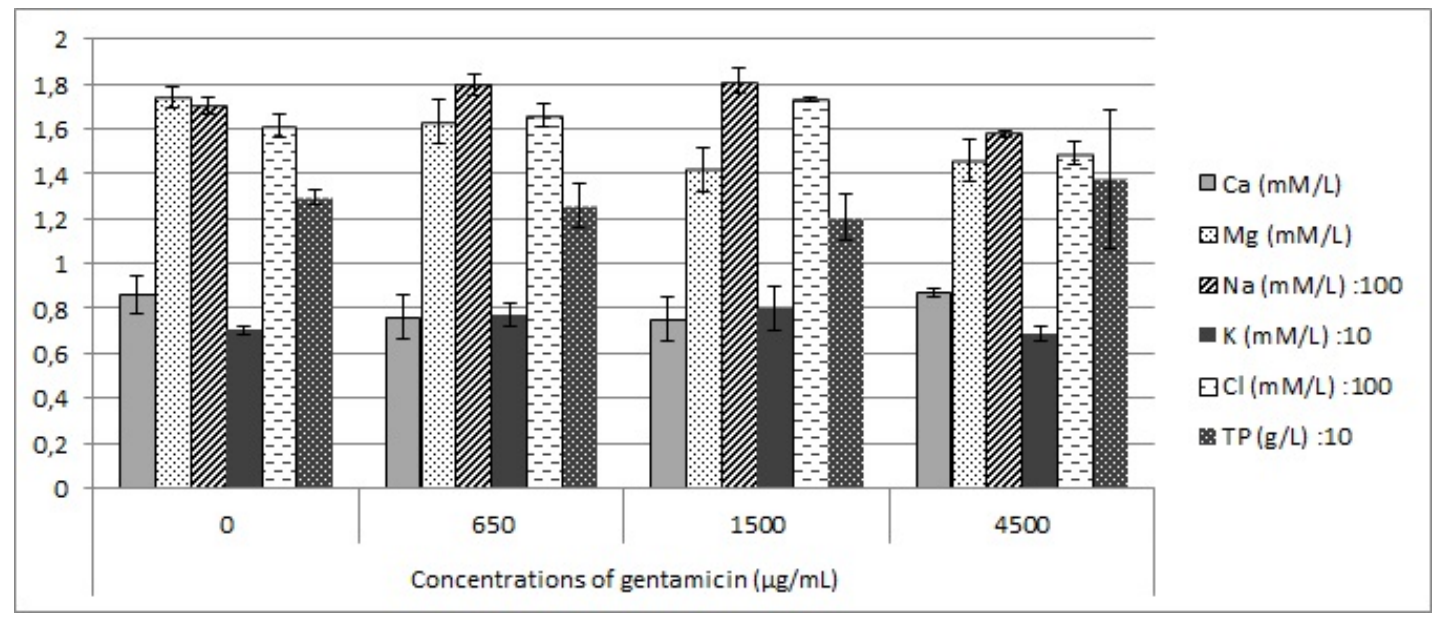

Figure 3. Levels of total proteins and mineral parameters in the medium after GENT application

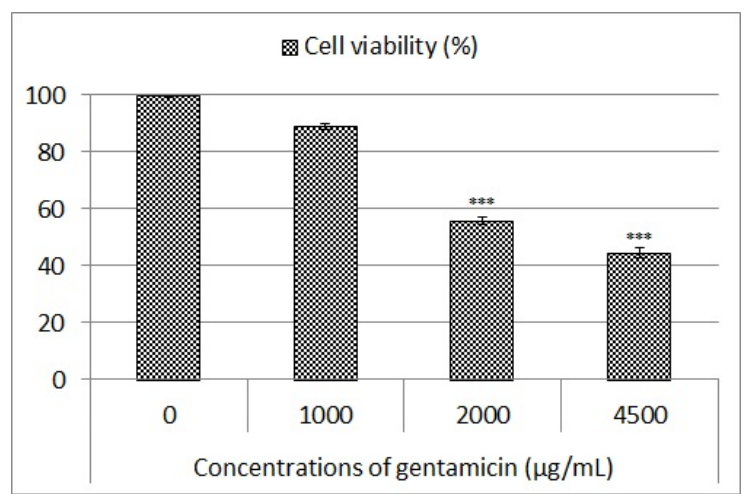

Figure 4. The effect of gentamicin (GENT) on the viability of selected mammalian cells; ${ }^{* *}(P<0.001)$; ${ }^{* *}(P<0.01) ;{ }^{*}(P<0.05)$

The members of the aminoglycoside antibiotics have the possible impact for nephrotoxicity, ototoxicity, and, infrequent, neuromuscular blockade. The risk of toxicity may be decreased as mechanisms are understood, new dosage strategies introduced, concomitant risk factors avoided, and shorter drug courses used [3].

Aminoglycosides, principally gentamicin induces mesangial cell contraction and proliferation. Simultaneously with the proliferative effect, gentamicin induces mesangial cell apoptosis in renal glomeruli and cultured mesangial cells [1]. Mechanisms of gentamicin nephrotoxicity include several ways: Gentamicin enhances the production of hydroxyradicals [19]; increases in the renal cortical phospholipidosis [20]; gentamicin inhibits $\mathrm{Na}^{+}-\mathrm{K}^{+}$-ATPase in renal tubule cells [21]; thromboxane A2 $\left(\mathrm{TXA}_{2}\right)$ and prostaglandins (PGE) increasing [22]; effect on renal protein synthesis [23]; Iysosomal [24] and mitochondrial injury [25]. Combination of these effects could induce acute renal failure [26]. Gentamicin toxicity also induces intracellular oxidative stress [27].
In our previous studies $[13,14,16]$ we tested the effect of macrolide antibiotics (tilmicosin, tylosin and spiramycin) on the selected mammalian cell lines (BHK 21, FE and Vero) in vitro. All tested antibiotics showed negative changes in the cell viability and cytomorphology. However, similar effect has been reached at lower concentration of antibiotics in the comparison with gentamicin.

Rathbone et al. [28] tested aminoglycosides (amikacin, tobramycin, and gentamicin), tetracyclines (minocycline, doxycycline) carbapenem, glycopeptide, penicillin and other antibiotics effect on osteogenic cell viability and in vitro activity. Human osteoblasts reacted very differently on the antibiotic dose and type. The antibiotics with the highest inhibition included rifampin, tetracyclines and ciprofloxacin, where $>75 \%$ decrements in cell number were measured at $100 \mu \mathrm{g} / \mathrm{mL}$. On the other hand, human osteoblast cells showed decline of cell number $(>75 \%)$ after higher doses of gentamicin (2000 $\mu \mathrm{g} / \mathrm{mL}$ ), which corresponds with our results.

In vivo study [29] presented kidney injury in rats (cell shrinkage and cytoplasm eosinophilia) after 
10 days with $10 \mathrm{mg}$ of gentamicin per $\mathrm{kg}$, where, however was not confirmed correlation between aminoglycoside and induced tubular apoptosis and cortical proliferative with phospholipidosis.

\section{Conclusions}

Many factors affect the effect of antimicrobial substances. Observed aminoglycoside (gentamicin) affects cells in different ways. Compared cellular lines reacted differently to each concentration. Another factor affecting chemical substance effect on eukaryotic cells is presence of carriers and excipients. Biologically active substances don't enter the body in clean form, but as a part of medical formula which is extended with adjuvants, which can extend or reduce the ultimate effect of active substance.

Acquired knowledge might be possibly applied in toxicity evaluation of pharmacological effective substances in vitro. Eukaryotic cells respond to chemical substances sensitively under in vitro conditions, therefore these techniques could replace in vivo examinations, which require great numbers of experimental animals.

\section{Acknowledgements}

The Ministry of Education, Science, Research and Sport of the Slovak Republic projects financially supported this work: VEGA 1/0039/16, KEGA 006/SPU-4/2015; Slovak Research and Development Agency financially supported this work: grant no. APVV-0304-12, APVV-15-0543. This work was also supported by AgroBioTech Research Centre built in accordance with the project Building „AgroBioTech" Research Centre ITMS 26220220180.

\section{References}

1. Martinez-Salgado, C., Lopez-Hernandez, F. J., Lopez-Novoa, J. M. (2007). Glomerular nephrotoxicity of aminoglycosides. Toxicology and applied pharmacology, 223(1), 86-98, https://doi.org/10.1016/j.taap.2007.05.004

2. Balakumar, P., Rohilla, A., Thangathirupathi, A. (2010). Gentamicin-induced nephrotoxicity: do we have a promising therapeutic approach to blunt it?. Pharmacological Research, 62(3), 179-186, https://doi.org/10.1016/j.phrs.2010.04.004

3. Bennett, J. E., Dolin, R., Blaser, M. J. Mandell, Douglas. (2015). Bennett's principles and practice of infectious diseases, eight ed., Elsevier Health Sciences, pp. 310-321.

4. Noone, P., Parsons, T. M. C., Pattison, J. R., Slack, R. C. B., Garfield-Davies, D., Hughes, K. (1974). Experience in monitoring gentamicin therapy during treatment of serious gram-negative sepsis. British Medical Journal, 1, 477-481.

5. Miglioli, P. A., Silini, R., Carzeri, O., Grabocka, E., Allerberger, F. (1999). Antibacterial activity of gentamicin and ciprofloxacin against gram-negative bacteria: interactions with pig and calf sera. Pharmacological research, 39, 321-323, https://doi.org/10.1006/phrs.1998.0447

6. Dehne, N., Rauen, U., De Groot, H., \& Lautermann, J. (2002). Involvement of the mitochondrial permeability transition in gentamicin ototoxicity. Hearing research, 169(1), 47-55. https://doi.org/10.1016/S0378-5955(02)00338-6

7. Forge, A., Schacht, J. (2000). Aminoglycoside antibiotics. Audiology and Neurotology, 5(1), 3-22, https://doi.org/10.1159/000013861

8. Isefuku, S., Joyner, C. J., \& Simpson, A. H. R. (2003). Gentamicin may have an adverse effect on osteogenesis. Journal of orthopaedic trauma, 17, 212216.

9. Duewelhenke, N., Krut, O., Eysel, P. (2007). Influence on mitochondria and cytotoxicity of different antibiotics administered in high concentrations on primary human osteoblasts and cell lines. Antimicrobial agents and chemotherapy, 51, 54-63, doi:10.1128/AAC.00729-05

10. Chung, W. H., Pak, K., Lin, B., Webster, N., \& Ryan, A. F. (2006). A PI3K pathway mediates hair cell survival and opposes gentamicin toxicity in neonatal rat organ of Corti. Journal of the Association for Research in Otolaryngology, 7(4), 373-382. DOI:10.1007/s10162006-0050-y

11. Ince, A., Schutze, N., Karl, N., Lohr, J. F., Eulert, J. (2007). Gentamicin negatively influenced osteogenic function in vitro. International Orthopaedics (SICOT), 31, 2007, 223-228. doi:10.1007/s00264-006-0144-5

12. Giguere, S., Prescott, J. F., Baggot, J. D., Walker, R. D., Dowling, P. M. (2007). Antimicrobial Therapy in Veterinary Medicine, fourth ed., WileyBlackwell, New York, p. 626.

13. Fülöpová, D., Kováčik, A., Kováčová, R., Čupka, P., Massányi, P. (2012). Effect of macrolide antibiotics on various cell cultures in vitro: Cell Morphology. The Journal of Microbiology, Biotechnology and Food Sciences, 2(1), 164-208.

14. Tvrdá, E., Kováčik, A., Fülöpová, D., Lukáč, N., Massányi, P. (2016). In Vitro Impact of Macrolide Antibiotics on the Viability of Selected Mammalian Cell Lines. Scientific Papers: Animal Science \& Biotechnologies, 49(2), 80-85.

15. Kováčik, A., Tušimová, E., Tvrdá, E., Fülöpová, D., Čupka, P., Tirpák, F., Zbyňovská, K., Massányi, P., Kolesárová, A. (2016). Influence of gentamicin on the specific cell culture (BHK-21) in vitro. The Journal of Microbiology, Biotechnology and Food Sciences, doi:10.15414/jmbfs.2016/17.6.3.983-986

16. Kováčik, A., Fülöpová, D., Kováčová, R., Čupka, P., Tušimová, E., Trandžík, J., Massányi, P. (2012). Effect of macrolide antibiotics on various cell cultures in vitro: 2. Cell biochemistry. The Journal of Microbiology, Biotechnology and Food Sciences, 2(3), 1079-1091.

17. Tvrdá, E., Lukáč, N., Lukáčová, J., Jambor, T., Massányi, P. (2015). Dose-and Time-Dependent In Vitro Effects of Divalent and Trivalent Iron on the Activity of Bovine Spermatozoa. Biological Trace Element Research, $167 \quad$ (1), 36-47. https://doi.org/10.1007/s12011-015-0288-5

18. Yu, H., Guo, C. K., Wang, Y., Zhou, T., Kong, W. J. (2014). Gentamicin Blocks the ACh-Induced BK 
Current in Guinea Pig Type II Vestibular Hair Cells by Competing with $\mathrm{Ca}^{2+}$ at the L-Type Calcium Channel. International journal of molecular sciences, 15, 67576771, doi:10.3390/ijms15046757

19. Shah, S. V., Walker, P. D. (1992). Reactive oxygen metabolites in toxic acute renal failure, Renal Failure, 14, 363-370.

20. Abdel Gayoum, A. A., Ali, B. H., Gawarsha, K., Bashir, A. A. (1993). Plasma lipid profile in rats with gentamicin nephrotoxicity. Human and Experimental Toxicology, 12 ,

$371-375$. DOI:10.1177/096032719301200505

21. Ali, B. H., Bashir, A. A., Tanira, M. O. M. (1995). The effect of thyroxine or carbimazole treatment on gentamicin nephrotoxicity in rats, Human and Experimental Toxicology, 14, 13-17. DOI:10.1177/096032719501400103

22. Papanikolaou, N., Peros, G., Morphake, P., Gkikas, G., Maraghianne, D., Tsipas, G., Kostopoulos, K., Arambtaze, C., Gkika, E-L., Bariety, J. (1992). Does gentamicin induce acute renal failure by increasing renal TX2 synthesis in rats. Prostaglandin Leuk. Essential Fatty Acids, 5, 131-136.

23. Sundin, D. P., Sandoval, R., Molitoris, B. A. (2001). Gentamicin inhibits renal protein and phospholipid metabolism in rats: implications involving intracellular trafficking. Journal of the American Society of Nephrology, 12(1), 114-123.

24. Servais, H., Van Der Smissen, P., Thirion, G., Van der Essen, G., Van Bambeke, F., Tulkens, P. M., Mingeot-Leclercq, M. P. (2005). Gentamicin-induced apoptosis in LLC-PK1 cells: involvement of lysosomes and mitochondria. Toxicology and applied pharmacology, 206(3), 321-333, https://doi.org/10.1016/i.taap.2004.11.024

25. Morales, A. I., Detaille, D., Prieto, M., Puente, A., Briones, E., Arévalo, M., Leverve, X., López-novoa, J.M., El-Mir, M. Y. (2010). Metformin prevents experimental gentamicin-induced nephropathy by a mitochondria-dependent pathway. Kidney international, 77(10), 861-869. http://dx.doi.org/10.1038/ki.2010.11 26. Ali, B. H. (1995). Gentamicin nephrotoxicity in humans and animals: some recent research. General Pharmacology: The Vascular System, 26(7), 14771487. https://doi.org/10.1016/0306-3623(95)00049-6

27. Sha, S. H., Schacht, J. (1999). Formation of reactive oxygen species following bioactivation of gentamicin. Free Radical Biology and Medicine, 26(3), 341-347, https://doi.org/10.1016/S0891-5849(98)00207$\mathrm{X}$

28. Rathbone, C. R., Cross, J. D., Brown, K. V., Murray, C. K. and Wenke, J. C. (2011). Effect of various concentrations of antibiotics on osteogenic cell viability and activity. Journal of Orthopaedic Research, 29, 1070-1074, DOI:10.1002/jor.21343

29. El Mouedden, M., Laurent, G., Mingeot-Leclercq, M. P., Taper, H. S., Cumps, J., Tulkens, P. M. (2000). Apoptosis in renal proximal tubules of rats treated with low doses of aminoglycosides. Antimicrobial agents and chemotherapy, 44(3), 665-675. 